\title{
NUANSA MAQHASID AL-SYARIAH DALAM UNDANG-UNDANG NOMOR 39 \\ TAHUN 1999 TENTANG HAK ASASI MANUSIA
}

\section{Muwaffiq Jufri}

\section{Fakultas Hukum Universitas Islam Madura}

Email : muwaffiq.jufri@gmail.com

\begin{abstract}
The essence of human rights is to protect and ensure the glory and dignity of people. So it becomes important human rights principles stipulated in the legislation in order to guarantee the state of human rights can be implemented optimally. However, there are some parties who deliberately rammed by the Islamic Human Rights as a product of the Liberals are opposed to the Sharia. In fact, both Islam and human rights, aimed at ensuring the glory and dignity of man as the principles "maqhasidu al-syari'ah" are the main objectives the implementation of Islamic law. This paper aims to prove that human rights are not contrary to Islam because it has been expressly stipulated that one-on-one purpose in religion is upholding human dignity. This paper uses legal research methods that reveal the fact that Islam protects personal rights of his people so that the necessary regulatory and enforcement of human rights in the Indonesia.
\end{abstract}

Keywords: Maqashid, Sharia, Human Right, and Indonesian

\begin{abstract}
Abstrak
Hakikat hak asasi manusia (HAM) ialah untuk melindungi dan menjamin kemuliaan dan martabat manusia. Sehingga menjadi penting prinsip-prinsip HAM diatur dalam peraturan perundang-undangan agar jaminan negara terhadap HAM dapat dilaksanakan secara maksimal. Meski demikian, terdapat beberapa pihak yang sengaja membenturkan HAM dengan Islam seolah HAM merupakan produk kaum Liberal yang bertentangan dengan Syariah Islam. Padahal, baik Islam maupun HAM, bertujuan untuk menjamin kemuliaan dan martabat manusia sebagaimana prinsipprinsip maqhasidu al-syariah yang menjadi tujuan utama diberlakukannya syariah Islam. Tulisan ini bertujuan untuk membuktikan bahwa HAM tidak bertentangan dengan Islam karena telah diatur secara tegas bahwa salah-satu tujuan dalam beragama ialah tegaknya martabat kemanusiaan. Tulisan ini menggunakan metode penelitian hukum normatif yang mengungkap fakta bahwa Islam melindungi hak-hak pribadi umatnya sehingga diperlukan pengaturan dan penegakan HAM dalam kontek negara hukum Indonesia.
\end{abstract}

Kata Kunci : Maqashid, Syariah, HAM, dan Indonesia

\section{Pendahuluan}

Hak Asasi Manusia, atau biasa disebut HAM, merupakan seperangkat hak yang melekat pada masing-masing individu sebagai anugerah Tuhan Yang Maha Kuasa. Karenanya, pemenuhan, perlindungan, dan penjaminan terhadapnya wajib dipenuhi oleh negara agar tidak terjadi aksi perampasan 
terhadap seperangkat hak tersebut. ${ }^{1}$ Dan tindak dapat dibenarkan, suatu tindakan yang merampas dan mengerdilkan HAM itu. Karena keberedaan HAM sejatinya merupakan bagian inti dari hakikat kemuliaan manusia sebagai makhluk paling sempurna (laqot kholaqna al-insaana fii ahsani taqwim).

Menurut Tholchah Hasan, HAM bukanlah produk liberal, melainkan produk dan prinsip kaum muslimin tentang kesetaraan. Prinsip ini telah ada semenjak masa nabi dan khulafaur-rasyidin. Dalam khazanah islam, dikenal suatu prinsip al-musawwa, yakni prinsip kesetaraan dalam menjalankan roda pemerintahan. Keberadaan al-musawwa inilah yang menjadi dasar prinsipil bahwa HAM merupakan muatan syariah Islam. Oleh karenanya, keberadaan HAM dalam bingkai negara republik Indonesia merupakan suatu keharusan sebagai implementasi dari syariah Islam yang menganjurkan kesetaraan antar umat mansuia. ${ }^{2}$

Oleh karena alasan di atas, maka negara Indonesia memberikan pengaturan terhadap HAM, agar pemenuhan HAM terhadap seluruh rakyat Indonesia dapat terlaksana dengan baik dan maksimal. Dengan payung peraturan perundang-undangan, keberadaan HAM memiliki dasar legitimasi untuk dipertahankan. Kalaupun terjadi perampasan terhadapnya, maka terdapat upaya hukum yang digunakan untuk memulihkan hak yang dirampas itu. ${ }^{3}$

Sejauh ini, telah ada beberapa aturan perundang-undangan yang memberikan peraturan terhadap HAM. Antara lain, seperti: Pasal 28A hinga Pasal 28J Undang-Undang Dasar Negara Republik Indonesia Tahun 1945 (UUD NRI 1945); Undang-Undang Nomor 39 Tahun 1999 Tentang Hak Asasi Manusia (UU HAM); Undang-Undang Nomor 11 Tahun 2005 Tentang Pengesahan Konvenan Internasional Tentang Hak-Hak Ekonomi, Sosial dan Budaya; Serta Undang-Undang Nomor 12 Tahun 2005 Tentang Pengesahan Konvenan Internasional Tentang Hak-Hak Sipil dan Politik (UU ICCPR). Dari berbagai aturan hukum tentang HAM itu, salah-satu yang sering dijadikan payung hukum dan menjadi jaminan terkait perlindungan adalah UU HAM.

Meski demikian, polemik tentang keberadaan HAM masih menjadi perdebatan runyam oleh berbagai kalangan di negeri ini. ${ }^{4}$ Dentuman perdebatan itu terasa makin panas manakala membahas mengenai hubungan

${ }^{1}$ Lihat ketentuan Pasal 1 Ayat (1) Undang-Undang Nomor 39 Tahun 1999 Tentang Hak Asasi Manusia.

2 Tholchah Hasan, "Hak Sipil dan Hak Politik Rakyat dalam Wacana Fiqih", dalam Khazanah; Jurnal Aswaja dan Keislaman, Edisi II Tahun 1999. (Malang: Pusat Studi Aswaja dan Keislaman, Universitas Islam Malang), h. 215.

3 Philipus M. Hadjon. "Perlindungan Hukum Bagi Rakyat", dalam Adam Muhshi, Teologi Konstitusi; Hukum Hak Asasi Manusia Atas Kebebasan Beragama di Indonesia, (Yogyakarta: LKiS, 2014) h. 18.

4 Agung Ali Fahmi, “Strategi Pemasyarakatan Hak Asasi Manusia dalam Masyarakat yang Plural", Jurnal Konstitusi PKK Fakultas Hukum Universitas Trunojoyo Madura, Vol. II No. 1 2011, h. 123. 
HAM dengan agama. Pihak yang sepakat menganggap bahwa HAM merupakan jaminan Tuhan terhadap umatnya yang keberadaannya wajib dihormati sebagai bukti ketaatan. Sedang bagi yang menolak, menganggap HAM merupakan produk kaum jahil yang tujuannya untuk memecah-belah umat Islam. ${ }^{5}$

Kajian ini penting dilakukan sebagai salah-satu usaha penemuan formalitas syariah Islam dalam muatan Undang-Undang Nomor 39 tahun 1999 Tentang HAM. Ini penting dilakukan mengingat beberapa orang (kelompok) di negeri ini beranggapan bahwa HAM merupakan produk barat yang bertentangan dengan syariah Islam. ${ }^{6}$ Mereka berpandangan bahwa mendirikan negara Islam adalah satu-satunya alternatif memecahkan persoalan bangsa. ${ }^{7}$

Disamping itu, pelaksanaan kajian ini ialah sebagai dasar argumentasi bahwa prinsip peraturan perundang-undangan yang diberlakukan di negeri ini, utamanya UU HAM, seyogyanya telah mengakomodasi rambu-rambu yang ditetapkan oleh syariah. Tentunya, rambu syariah dalam aras ini ialah tentang kesejahteraan, keadilan, hubungan antar manusia, khususnya prinsip-prinsip yang terkandung dalam maqhasidu al-syariah yang mencitrakan Islam sebagai agama rahmah, bukan agama marah. (Rahmatan lil 'alamin)

Berdasarkan beberapa uraian di atas, kajian yang penting untuk dilakukan ialah ditelusurinya prinsip-prinsip maqhasid al-syari' ah dalam UU HAM, karena pada prinsipnya tujuan diundangkannya UU HAM ialah untuk menjamin hak-hak asasi yang dimiliki setiap manusia, di mana hakhak tersebut menjadi instrumen dalam mewujudkan hakikat kemuliaan serta martabat manusia.

\section{Pembahasan}

\section{Hak Asasi Manusia dan Maqashid al-Syariah dalam Islam}

5 Cekly Setya Pratiwi, "Penghormatan dan Perlindungan Hak Asasi Manusia: Hak Kebebasan Beragama dan Berkeyakinan di Indonesia", dalam Syamsul Arifin, dkk (Editor), Hak Asasi Manusia Untuk Kebebasan Beragama di Indonesia; Keniscayaan, Kenyataan, dan Penguatan, (Malang; PUSAM Bekerjasama dengan The Asia Fundation, 2015), h. 205.

${ }^{6}$ Dalam Tulisan Hizbut Tahrir Indonesia (HTI) yang berjudul "Liberalisasi Budaya Merusak Bangsa", kelompok ini berpendapat bahwa liberalisasi budaya itu dikemas dalam berbagai program secara internasional yang dikawal langsung oleh PBB dengan mengeluarkan berbagai konvensi dan kesepakatan internasional terkait dengan isu HAM, kesetaraan gender, dan lain-lain, yang spiritnya sama-sama menuntut kebebasan dan kesetaraan laki-laki dan perempuan. Kemudia negara-negara dunia ketiga (termasuk Indonesia) dipaksa meratifikasi berbagai aturan tersebut. Oleh karenanya lahirlah berbagai aturan perundang-undangan yang mengatur tentang kebebasan dan kesetaraan.

7 Argumen ini bisa dilihat pada tulisan HTI yang lainnya dengan judul "Dalil mendirikan Negara Berdasarkan Syariat Islam". Tulisan ini mencoba membantah argumen kelompok yang dianggap liberalis dan menolak pendirian negara Islam Indonesia. 
Hak Asasi Manusia (HAM) terdiri dari tiga rangkaian kata, yakni hak, asasi dan manusia. Kata hak merupakan serapan serapan dari bahasa arab berupa "haqq", yang berakar dari kata "haqqa-yahiqqu-haqqaan" yang artinya benar, nyata, pasti, tetap, dan wajib. Berdasarkan hal tersebut, maka yang disebut hak berarti suatu kewenangan atau kewajiban untuk melakukan sesuatu atau tidak melakukan sesuatu.

Sedangkan kata asasi berasal dari bahasa arab "asasy' yang berakar dari kata "assa-yaussu-asasaan" yang artinya membangun, mendirikan, dan meletakkan. Kata tersebut dapat juga diatikan asal, asas, pangkal, atau dasar dari segala sesuatu. Dengan demikian, asasi artinya segala sesuatu yang bersifat mendasar dan fundamental yang selalu melekat pada objeknya, yakni manusia. Singkatnya, HAM diartikan sebagai hak-hak yang mendasar yang melekat pada diri manusia. ${ }^{8}$

Sekalipun terdapat beberapa perbedaan pandangan di antara para fuqaha $^{\prime 9}$ mengenai apa yang dimaksud dan bagaimana aplikasi hak itu, namun menurut Ebrahim Moosa, hak (haqq) diartikan sebagai sesuatu yang sudah baku dan tidak dapat diingkari. Menurut Moosa, hak memiliki kesamaan dengan realitas dan/atau kebenaran. Dalam aras ini, hak merupakan lawan dari kata bathil. Lebih lanjut Moosa menjelaskan bahwa kata haqq dapat leluasa berganti pemaknaan sesuai dengan kontek apa ia digunakan. ${ }^{10}$

Selanjutnya, terkait dengan HAM, dalam ajaran fiqih, terdapat ketentuan dasar yang menyatakan bahwa semua manusia memiliki status hukum yang sama (muhtaram), yakni tetap dihormati keberadaannya dan terdapat larangan untuk menyiksa dan membunuhnya. Manusia merupakan makhluk paling unggul daripada yang lainnya. Oleh karenanya, segala martabat dan kehormatan manusia itu wajib dilindungi dan tidak dibenarkan adanya perampasan terhadap martabat itu. Setiap perampasan hak akan mengurangi, menistakan, dan mengerdilkan kehormatan manusia. ${ }^{11}$

Pada konteks inilah terjadi pertemuan hubungan antara HAM dengan maqhasidu al-syariah yang menjadi tujuan akhir diberlakukan syariah Islam. Sebagaimana yang disampaikan oleh Al-Ghazali,12 Tujuan syariah meliputi : Perlindungan terhadap harta (hifdzu al-maal), perlindungan terhadap jiwa (hifdzu an-nafs), perlindungan terhadap keluarga dan keturunan (hifdzu al-nasl), perlindungan terhadap pikiran

\footnotetext{
8 Mujaid Kumkelo, dkk, Figh HAM; Ortodoksi dan Liberalisme Hak Asasi Manusia dalam Islam, (Malang: Setara Press, 2015), h. 43.

${ }_{9}$ Fuqaha' dalam bahasa Indonesia sebagai ahli fiqh, ulama' fiqh, atau orang yang memiliki penguasaan terhadap ilmu fiqh.

${ }^{10}$ Ebrahim Moosa dalam Mujaid Komleko, dkk, h. 44.

11 Ibid, h. 44.

12 Ahmad Nur Fuad, dkk, Hak Asasi Manusia dalam Prespektif Islam, (Malang; Kerjasama Madani dengan LPSHAM Muhammadiyah Jawa Timur, 2010), h. 11.
} 
(hifdzu al-aql) dan yang terakhir perlindungan terhadap agama (hifdzu aldien).

\section{Nuansa Maqashidu Al-Syariah dalam Undang-Undang Nomor 39 Tahun 1999 Tentang Hak Asasi Manusia}

Sebagaimana yang telah disampaikan pada uraian di atas mengenai pokok-pokok pengaturan HAM dalam UU HAM yang meliputi; hak untuk hidup, hak berkeluarga dan melanjutkan keturunan, hak mengembangkan diri, hak memperoleh keadilan, hak katas kebebasan pribadi, ha katas rasa aman, hak atas kesejahteraan, hak turut serta dalam pemerintahan, hak wanita, dan hak anak.

Masing-masing muatan tersebut terdapat beberapa hal urgen yang berkaitan langsung dengan syariah Islam dan menjadi sesuatu yang diutamakan perlindungannya serta penegakannya. Beberapa hal penting yang dimaksud antara lain hak untuk hidup, hak atas pengembangan diri dan karir, hak untuk berkeluarga dan mengembangkan keturunan, hak atas harta milik pribadi, serta hak dan kebebasan dalam beragama dan menjalankan ritual berdasarkan agama yang diyakini. Kesemua hak itulah yang menjadi muatan dari maqashidu al-syariah.

\section{Hak Untuk Hidup (Hifdzu Al-Nafs)}

Terkait dengan hak untuk hidup, UU HAM memberikan pengaturan bahwa pada pokoknya, setiap orang berhak untuk hidup dan mempertahankan kehidupannya dengan rasa aman, tentram, dan bahagia, baik secara lahiriah maupun batiniah. ${ }^{13}$ Dengan begitu, hak untuk hidup sejahtera merupakan hak dasar yang dimiliki oleh seluruh rakyat Indonesia tanpa terkecuali. Ini ditandai dengan awalan kata "setiap orang" yang mengandung arti seluruh rakyat Indonesia.

Menurut Agung Ali Fahmi,14 Kata "setiap orang" berarti "semua orang", tidak membedakan ras, suku, warga negara mana, dan latar belakang primordial lainnya. Dengan demikian, pasal ini memang ditujukan untuk melindungi hak asasi yang paling asasi yang melekat erat pada diri mansia, berlaku universal dan lintas batas territorial, adat, budaya, serta perbedaan soaial-politik lainnya. Oleh karenanya, seluruh lapisan masyarakat Indonesia, di manapun ia tinggal, berhak menikmati keberadaan hak untuk hidup secara aman, damai, dan sejahtera tanpa adanya gangguan dari pihak manapun, termasuk negara.

Ketentuan dalam pasal ini sangat sesuai dengan muatan maqashidu al-syariah yang memberikan kebebasan dasar bagi umat muslim untuk hidup dan mempertahankan kehidupannya. Islam

\footnotetext{
${ }^{13}$ Lihat ketentuan Pasal 9 Ayat (1), Pasal 9 Ayat (2) dan Pasal 9 Ayat (3) UU HAM.

14 Agung Ali Fahmi, Implementasi Jaminan Hukum HAM Atas Kebebasan Beragama di Indonesia, (Yogyakarta: Interpena, 2011), h. 147.
} 
sangat memuliakan manusia dan mengutuk tindakan yang merendahkan hakikat kemuliaan dan martabat manusia. Sebagaimana asas al-Karamah al-Insaniyah atau kehormatan insani yang memberikan kepadanya suatu martabat yang tinggi yaitu martabat kemanusiaan. ${ }^{15}$ Bahkan, dari mulianya manusia sebagai makhluk, Allah SWT dengan nyata memberikan kemulyaan kepada anak-cucu Adam sebagaimana yang terkandung dalam Surah Al-Isro' Ayat 70, berbunyi $: 16$

Dan sesungguhnya telah Kami muliakan anak-anak Adam, Kami angkut mereka di daratan dan di lautan, Kami beri mereka rezeki dari yang baikbaik dan Kami lebihkan mereka dengan kelebihan yang sempurna atas kebanyakan makhluk yang telah Kami ciptakan.

Dalam Islam, hak untuk hidup adalah hak yang hakiki dan suci, keberadaannya tidak memerlukan persetujuan sosial atau semacamnya, karena merupakan karunia yang diberikan Allah SWT kepada setiap manusia. Karenanya, siapapun orangnya, tidak punya kuasa untuk menghidupkan dan mematikan seseorang kecuali atas kehendak Allah SWT. ${ }^{17}$ Karenanya, setiap manusia mempunyai hak yang sama untuk hidup dan mempertahankan kehidupannya secara bebas dan wajar.

Bahkan menurut Masdar Farid Mas'udi, hak untuk hidup merupakan hak dasar yang paling utama disebut, karena merupakan tumpuan dari hak-hak lainnya. Karenanya, untuk menjamin kemerdekaan kehidupan manusia tersebut, Allah memberlakukan qishas sebagai hukuman atas seseorang yang membunuh orang lain. Bila dielaborasikan lebih jauh, keberadaan qishas sebetulnya menjadi langkah prefentif (pencegahan) agar manusia tidak membunuh manusia yang lainnya karena akan berhadapan dengan qishas. Dengan qishas maka kehidupan manusia akan lebih terjamin dan terlindungi. ${ }^{18}$

Dengan redaksi yang sedikit berbeda, Ash-Sabuni menyatakan bahwa siapa yang membunuh jiwa tanpa sebab jinayat, maka seakanakan dia telah membunuh semua manusia, karena tidak adanya perbedaan antara jiwa yang satu dengan yang lainnya. Dan barang yang menghidupkannya, maka berarti ia telah menyelamatkan manusia seluruhnya. Lebih lanjut, Ash-Sabhuni menerangkan bahwa membuat kerusakan di bumi ini sama artinya dengan membunuh

\footnotetext{
15 Ahmad Nur Fuad, dkk, h. 10.

16 Muzhaf Al-Azhar, Al-Qur'an dan Terjemahannya, (Bandung: Penerbit Hilal, 2010), h. 290.

17 Lihat Surat Al-Hijr Ayat 3.

18 Masdar Farid Mas'udi, Syarah UUD 1945 Perpektif Islam, (Jakarta: Kerjasama Pustaka Alfabet dengan LaKIP, 2013), h. 199.
} 
manusia, karena perbuatan itu merupakan ancaman untuk kelangsungan hidup manusia.

Terkait dengan hak hidup, Deklarasi Kairo juga memberikan jaminan bahwa kehidupan merupakan anugerah Tuhan dan hak hidup dijamin bagi setiap orang. Karenanya, deklarasi ini memberikan amanah kepada masyarakat dan negara untuk wajib melindungi hak ini dari segala bentuk pelanggaran apapun, dan dilarang untuk mencabut hak hidup seseorang kecuali berdasarkan alasan yang sudah ditentukan syariat (peraturan perundang-undangan). ${ }^{19}$

\section{Hak Atas Kebebasan Berfikir (Hifdzu Al-Aql)}

Pasal 4 UU HAM menegaskan bahwa hak untuk berfikir merupakan hak dasariah yang keberadaan wajib dihormati dan dipenuhi, serta merupakan suatu pelanggaran jika keberadaan tersebut diganggu, dirampas, dan dikerdilkan. Posisi hak ini bahkan disetarakan dengan hak-hak dasar yang lain seperti hak untuk hidup, hak beragama, hak persamaan di depan hukum, hak tidak diperbudak, dan hak-hak dasar lain yang menandakan kemuliaan martabat manusia. ${ }^{20}$

Kebebasan berpikir merupakan hak paling asasi yang dimiliki oleh manusia sebagai makhluk ciptaan Sang Kuasa. Dengan pikiran, manusia mampu membedakan mana yang haq dan mana yang batil. Karena pikiran itulah, derajat manusia sebagai makhluk lebih tinggi dari makhluk-makhluk ciptaan Tuhan yang lainnya. Hal ini menjadi tanda bahwa posisi akal pikiran merupakan suatu hal yang tidak bisa dipisahkan dari harga diri, kehormatan, dan martabat manusia. ${ }^{21}$

Dalam Islam, posisi akal pikiran merupakan sesuatu yang paling berharga yang dimiliki oleh umat manusia. Bahkan Allah SWT, berulangkali menyuruh, menyindir, dan memerintahkan manusia untuk selalu berfikir atas segala kejadian alam semesta ini. Perintah Tuhan dalam berbagai ayat tersebut biasanya dilakukan di akhir ayat dengan redaksi: afalaa ta'qiluun, afalaa tatafakkarun, afalaa tatadabbarun ? atau dalam beberapa ayat disebutkan dengan redaksi inna fii dzaalika la'ayaatin liqaumin yatafakkaruun.22

Selaras dengan hal tersebut di atas, Deklarasi Kairo Tentang Hak Asasi Manusia memberikan jaminan dan kebebasan kepada semua umat muslim untuk bebas berfikir dan menentukan sikap dan pendapatnya. Tentu kebebasan tersebut tidak boleh melapaui ramburambu yang telah ditetapkan syariah Islam dengan tujuan agar tidak

\footnotetext{
${ }^{19}$ Lihat ketentuan Pasal 2 Ayat (1) Deklarasi Kairo Tentang Hak Asasi Manusia.

${ }^{20}$ Lihat Pasal 4 UU HAM.

21 Muhammad Nur Islami, Hukum dan Kebebasan Berpikir, (Yogyakarta: Pustaka Pelajar, 2015), h. 39.

22 Muhammad Nur Islami, Ibid, h. 40-41.
} 
bersinggungan dengan keberadaan hak-hak yang lainnya. ${ }^{23}$ Deklarasi ini menegaskan bahwa kebebasan berfikir tidak terbatas hanya kebebasan untuk berfikir tetapi juga kebebasan untuk menyampaikan pendapat atas apa yang dihasilkan dari usaha berfikir tersebut.

\section{Hak dan Kebebasan Atas Harta Benda (Hifdzu Al-Maal)}

Pasal 29 Ayat (1) UU HAM memberikan jaminan bahwa "setiap orang berhak atas perlindungan diri-pribadi, keluarga, kehormatan, martabat, dan hak miliknya". Kata hak milik ini diindikasikan sebagai kebebasan dan perlindungan terhadap manusia atas segala hak yang dimilikinya, salah-satu hak milik tersebut adalah hak kepemilikan atas harta benda.

Kebutuhan seseorang atas harta benda didasarkan pada hakikat manusia yang memiliki ketergantungan terhadap benda lain di luar dirinya, yakni sandang, pangan, dan papan. Oleh karenanya, keberadaan harta benda yang menjadi kebutuhan dasar manusia agar tetap bisa melanjutkan kehidupan dan menjalin hubungan antar sesama, wajib dilindungi dan dipenuhi kebutuhannya agar manusia bisa dengan layak hidup dan mengarungi kehidupan di dunia ini.Keberadaan harta benda tersebut wajib dilindungi agar tidak mudah dirampas, dirampok, dan dikurangi oleh orang lain. Karenanya, perlindungan yang diberikan UU HAM terhadap hak atas kepemilikan harta benda merupakan suatu langkah prestisius yang sangat bermanfaat bagi pengembangan kehidupan manusia agar tidak terancam dari kepunahan. ${ }^{24}$

Sebagai agama pelengkap atas risalah-risalah agama sebelumnya, Islam memberikan perlindungan atas keberadaan harta benda yang dimiliki oleh manusia. Dalam Surat Al-Baqarah Ayat 188 Allah berfirman :25

"Dan janganlah sebahagian kamu memakan harta sebahagian yang lain di antara kamu dengan jalan yang bathil dan (janganlah) kamu membawa (urusan) harta itu kepada hakim, supaya kamu dapat memakan sebahagian daripada harta benda orang lain itu dengan (jalan berbuat) dosa, Padahal kamu mengetahui."

Dalam ayat yang lain, An-Nisa ayat 29, Allah juga berfirman :26 "Hai orang-orang yang beriman, janganlah kamu saling memakan harta sesamamu dengan jalan yang batil, kecuali dengan jalan perniagaan yang berlaku dengan suka sama-suka di antara kamu. dan janganlah kamu membunuh dirimu; Sesungguhnya Allah adalah Maha Penyayang kepadamu"

\footnotetext{
${ }^{23}$ Lihat Pasal 22 Ayat 1 Deklarasi Kairo.

24 Masdar Farid Mas'udi, h. 208-209.

${ }^{25}$ Muzhaf Al-Azhar, h. 29.

${ }^{26} \mathrm{Ibid}, \mathrm{h} .83$
} 
Kedua ayat tersebut menunjukkan bahwa Islam begitu reaktif dalam upaya memberikan perlindungan atas keberadaan harta benda yang dimiliki oleh setiap manusia. Tidak hanya memberikan perlindungan, Tuhan juga mengutuk orang-orang yang gemar memperoleh harta dari jalan yang tidak benar dan dholim. Harta yang tidak diperoleh secara syar'i akan menyebabkan terampasnya hak milik orang lain. Oleh karenanya, agar harta yang dimiliki berkah, hendaklah berusaha diperoleh dari jalan yang benar tanpa menyekiti dan merampas hak milik yang lainnya.

Selaras dengan keterangan di atas, Deklarasi Kairo memberikan perlindungan secara transparan dan nyata terhadap keberadaan hak milik terhadap harta benda. Pada Pasal 15 Ayat (1) disebutkan bahwa "setiap orang berhak memiliki harta kekayaan dengan cara yang sah, dan diberi hak untuk memiliki harta kekayaan tanpa prasangka terhadap diri-sendiri, orang lain, atau masyarakat pada umumnya. Pengambil-alihan tidak dibolehkan kecuali untuk kepentingan umum dengan pembayaran ganti rugi yang adil dan segera".

Menurut Mujaid Komleko, ${ }^{27}$ pemaknaan terhadap jaminan terhadap harta benda ini tidak hanya menjamin seseorang bebas memiliki harta tanpa adanya gangguan dari siapapun, tetapi juga terdapat jaminan terhadap keluesan setiap orang untuk bekerja dengan tujuan mendapatkan nafkah yang layak sebagai bekal untuk melanjutkan hidup dan kehidupan.

4. Hak Atas Kebebasan Berkeluarga dan Melanjutkan Keturunan (Hifdzu Al-Nasli)

Membahas tentang keluarga dan melanjutkan keturunan memang selalu menarik minat banyak orang untuk mengkajinya. Hal ini dikarenakan keberadaan keluarga merupakan hal yang urgen agar keberlangsungan kehidupan umat manusia di muka bumi ini bisa dipertahankan dari ancaman kepunahan. Dan merupakan pemenuhan dari hakikat manusia sebagai zon politicon, atau makhluk bersosial yang dalam hidupnya membutuhkan hubungan sosial antara yang satu dengan yang lainnya.

Sehubungan dengan hal tersebut di atas, negara telah memberikan perlindungan terhadap keberadaan keluarga dan kebebasan melanjutkan keturunan ini. Salah-satunya jaminan yang diberikan oleh UU HAM. Dalam UU HAM, keberadaan hak untuk berkeluarga dan melanjutkan keturunan diatur secara tersendiri pada bagian kedua yang membawahi Pasal 10. Pada Pasal 10 Ayat (1) disebutkan bahwa "Setiap orang berhak membentuk suatu keluarga dan melanjutkan keturunan melalui perkawinan yang sah".

${ }^{27}$ Mujaid Komleko, dkk, h. 49. 
Pasal ini memberikan jaminan dan perlindungan bahwa siapapun orangnya, berhak berkeluarga, atau hidup berkeluarga, dan atas keluarga tersebut melahirkan ketentuan selanjutnya tentang hak dan kebebasan seseorang untuk melanjutkan keturunan. Keturunan inilah yang nantinya menjadi generasi penerus kehidupan umat manusia. Tanpa memiliki keturunan, manusia akan merasakan kehampaan yang luar biasa serta jika tidak berketurunan, maka berpotensi terhadap punahnya estafet kepemimpinan umat manusia di muka bumi (khalifatullah fi al-ard).

Pada ayat selanjutnya, Pasal 10 Ayat (2), memberikan perlindungan atas kebebasan masing-masing mempelai (laki-laki dan perempuan) untuk bebas menentukan pasangan hidupnya. Redaksi lengkap pasal ini ialah "Perkawinan yang sah hanya dapat berlangsung atas kehendak bebas calon suami dan calon istri yang bersangkutan, sesuai dengan ketentuan peraturan perundang-undangan". Artinya, selain seseorang itu bebas berkeluarga, ia juga bebas memilih dengan siapa ia hendak mengarungi bahtera rumah-tangga.

Senafas dengan ketentuan di atas, Islam sangat menganjurkan ummatnya untuk berkeluarga dan melanjutkan keturunan. ${ }^{28}$ Terdapat banyak dalil Al-Qur'an yang menganjurkan manusia untuk berkeluarga. Salah-satu dan yang terpopuler ialah surat Ar-rum Ayat 21 yang berbunyi "Dan diantara tanda-tanda kekuasaanNya ialah Dia menciptakan untukmu isteri-isteri dari jenismu sendiri, supaya kamu cenderung dan merasa tenteram kepadanya, dan dijadikanNya diantaramu rasa kasih dan sayang. Sesungguhnya pada yang demikian itu benar-benar terdapat tanda-tanda bagi kaum yang berpikir" 29

Ayat di atas memberikan penjelasan bahwa untuk mencapai ketentraman, manusia diajurkan untuk menikah dan berkeluarga. Ini sesuai dengan hakikat manusia yang tidak bisa hidup sendiri tanpa adanya pendamping. Dengan adanya pendamping hidup, maka kehidupan seseorang akan cenderung lebih tentram, sejahtera, bahagia, dan damai.

Selaras dengan ketentuan di atas, Nabi Muhammad juga sangat menganjurkan ummatnya untuk berkeluarga. Bahkan Nabi Muhammad memberikan penegasan bahwa pernikahan adalah "laku" (sunnah)-nya Nabi, dan juga menegaskan barang-siapa yang tidak mengindahkan sunnah nabi maka dia bukanlah bagian dari golongan nabi. Redaksi lengkap Hadits tersebut ialah "Annikaahu sunnati, fa man raghiba 'an-sunnati, falaisa minni".

Sehubungan dengan hal tersebut di atas, Islam, melauli Deklarasi Kairo, begitu tegas memberikan perlindungan serta jaminan

\footnotetext{
${ }^{28}$ Masdar Farid Mas'udi, h. 201.

${ }^{29}$ Muzhaf Al-Azhar, h. 406.
} 
terhadap pemenuhan atas keberlangsungan hak untuk berkeluarga. Pada Pasal 5 Ayat (1) Deklarasi Kairo disebutkan bahwa "keluarga merupakan fondasi masyarakat, dan pernikahan merupakan landasan pembentukannya. Laki-laki dan perempuan mempunyai hak untuk menikah, dan tidak ada pembatasan apapun yang berdasarkan ras, suku, warna kulit, atau kebangsaan yang menghalangi mereka untuk menikmati hak ini".

\section{Hak Atas Kebebasan Beragama (Hifdzu Al-Dien)}

Persoalan mengenai kebebasan beragama dalam bingkai negara Indonesia akhir-akhir ini banyak menarik perdebatan dan kajian oleh berbagai kalangan. Hal ini tidak terlepas dari beberapa konflik dan kekerasan yang dilatar-belakangi oleh perbedaan agama dan keyakinan. Tragisnya, konflik berbasis agama ini terjadi di berbagai daerah di Nusantara. Ini menjadi potrek buruk yang berpotensi memecah-belah persatuan bangsa. Padahal, modal keberagaman yang dimiliki Indonesia seharusnya menjadi penguat bagi kemajuan dan persatuan bangsa. ${ }^{30}$

Bertolak dari hal tersebut di atas, terkait dengan hak dan kebebasan beragama, Muatan UU HAM sebenarnya telah memberikan pengaturan tentang hak dan kebebasan setiap warga-negara untuk memeluk, meyakini dan menjalankan ritual agama. Seperti yang tercantum dalam ketentuan Pasal 22 ayat (1) UU HAM yang berbunyi "setiap orang bebas memeluk agamanya masing-masing dan untuk beribadat menurut agamanya dan kepercayaannya itu". Pada pasal selanjutnya, Pasal 22 Ayat (2) UU HAM dipertegas bahwa jaminan terhadap kebebasan beragama menjadi tanggung-jawab negara. Bunyi pasal tersebut ialah "Negara menjamin kemerdekaan setiap orang memeluk agamanya masingmasing dan untuk beribadat menurut agamanya dan kepercayaannya itu". Artinya, selain negara memberikan jaminan terhadap pemenuhan hak dan kebebasan rakyat untuk meyakini agama dan menjalankan ritualnya, negara juga bertanggung-jawab atas jaminan pemenuhan hak tersebut. ${ }^{31}$

Sebagai agama yang menjadi rahmah bagi semua ummah (rahmatan lil-'alamin), Islam memberikan kebebasan bagi manusia untuk memeluk agama dan kepercayaan. Islam tidak pernah memaksa kepada manusia untuk menjadikan Islam sebagai agama yang

30 Zakiyuddin Baidhawi, “Piagam Madinah dan Pancasila; Prinsip-Prinsip Kehidupan Bersama dalam Berbangsa dan Bernegara", dalam Wawan Gunawan Abd. Wahid, Muhammad Abdullah Darraz, Ahmad Fuad Fanani. 2015. Fikih Kebinekaan; Pandangan Islam Indonesia Tentang Umat, Kewargaan, dan Kepemimpinan non-Muslim. Bandung: Kerjasama Mizan Pustaka dan Maarif Institute, h. 127.

${ }^{31}$ Muwaffiq Jufri, "Pembatasan terhadap Hak dan Kebebasan Beragama di Indonesia, Jurnal Pendidikan Pancasila dan Kewarganegaraan", Vol. 1 No. 1, 2016, h. 41. 
dipeluk, ${ }^{32}$ sebagaimana firman Allah dalam surat Al-Baqarah ayat 256 yang berbunyi "Tidak ada paksaan dalam agama. Sungguh telah nyata kenbenaran dan kesesatan. Karena itu barang siapa yang ingkar kepada Thagut dan beriman kepada Allah, sesunguhnya ia telah berpegang kepada tali yang amat kuat yang tak akan putus. Allah Maha Mendengar dan Mengetahui". ${ }^{33}$

Ayat tersebut diatas merupakan salah satu ayat yang bisa dijadikan dalil tentang tidak dibolehkannya melakukan pemaksaan apapun dalam kehidupan beragama. Dalam menafsirkan ayat ini, bahwa yang dimaskud dengan pemaksaan (al-ikrah) adalah alghayy dan ini adalah jalan salah (al-thariq al-khathi). Sedang yang dimaksud dengan tanpa paksaan (alla ikrah) adalah al-rusyd dan ini adalah jalan benar (al-thariq al-shalih). Pengertian ayat ini adalah "tidak ada paksaan dalam, sungguh sudah jelas perbedaan antara tanpa paksaan dan pemaksaan."

Menurut Salamun Ali Mafas ${ }^{34}$, Maksud berikut penafsiran dari ayat tersebut ialah, Pertama, ayat ini sangat jelas memberi jaminan kebebasan dan jaminan agar seseorang tidak dipaksa orang lain tentang hal apapun, termasuk dalam beragama. Kedua, ayat ini dapat dijadikan suatu pemahaman sebagai kalimat perintah (kalam insya'i) dan sebagai kalimat informatif (kalam ikhbari). Dalam posisinya sebagai kalimat perintah, ia menyuruh kepada orang lain agar tidak memaksakan agama kepada orang lain.

Sebagai kalam ikhbari, ayat ini dimaksudkan untuk memberikan informasi sesungguhnya seseorang yang dipaksa masuk pada suatu agama sementara hatinya menolak, maka orang itu tidak bisa dikatakan telah memeluk agama itu. hal ini dikarenakan agama ada di dalam kemantapan hati bukan dalam kata-kata.

Ketiga, tidak ada paksaan dalam beragama sama halnya tidak ada paksaan soal cinta, cinta tidak bisa datang dengan paksaan. Dengan demikian tidak ada agama dengan paksaan sebagaimana tidak ada paksaan dalam cinta. Dan keempat, ayat ini melarang membunuh orang lain yang pindah agama, karena ayat ini turun untuk melarang pemaksaan soal agama. Kelima, orang yang tidak menerima gagasan kebebasan beragama adalah orang yang tidak percaya dengan agama yang dianutnya. Agamanya tidak akan berkembang pesat sekiranya tidak dijalankan dengan paksaan, dengan alasan itu, mereka

32 Zakiyudin Baidhawi. Kredo Kebebasan Beragama. (Jakarta: PSAP Muhammadiyah, 2005), h. 79.

${ }^{33}$ Agung Ali Fahmi, h. 42.

34 Salamun Ali Mafaz. La Ikraha fiddin, Tafsir Humanis dalam Beragama. Dalam http:/ / lifestyle-kompasiana.com/catatan/2013/04/23/la-ikraha-fid-ad-din-tafsir-humanisdalam-beragama-554083.html, diakses 21 Oktober 2016. 
melakukan pemaksaan bahkan kekerasan agar orang lain masuk ke dalam agama yang dipeluk dirinya.

Selaras dengan maksud ayat di atas, Piagam Madinah memberikan kebebasan bagi setiap rakyat Madinah di zaman rasulullah diberikan kebebasan untuk memeluk agama dan menjalankan ritual agamanya. Ketentuan ini termaktub pada Pasal 25 Ayat (2), Pasal 26, Pasal 27, Pasal 28, Pasal 29, Pasal 30, Pasal 31, Pasal 32, Pasal 33, dan Pasal 34 Piagam Madinah. ${ }^{35}$

Selanjutnya, Deklarasi Kairo juga memberikan jaminan bahwa setiap orang berhak meyakini suatu agama dan menjalankan ritual agama sesuai yang diyakininya. Namun demikian, ketentuan ini memberi peringatan bahwa tidak diperkenankan tindakan eksploitasi kemiskinan atau ketidak-tahuan seseorang agar ia berpindah agama atau menjadi ateis. ${ }^{36}$

\section{Simpulan}

Berdasarkan pembahasan di atas, bahwa nuansa maqhosidu al-syari'ah dapat ditemui dalam beberapa dalam muatan UU HAM. Seperti Pasal 4 tentang kebebasan berfikir (hifdzu al-aql), Pasal 9 ayat (1), Pasal 9 Ayat (2) dan Pasal 9 Ayat (3) tentang hak untuk hidup dan mempertahankan kehidupan (hifdzu al-nafs), Pasal 29 Ayat 1 Tentang hak kepemilikan dan kesejahteraan (hifdzu al-maal), Pasal 10 Ayat (1) dan Pasal 10 Ayat (2) tentang hak untuk berkeluarga dan melanjutkan keturunan (hifdzu al-nasl), dan Pasal 22 Ayat (1) serta Pasal 22 Ayat (2) tentang kebebasan beragama dan menjalankan ritual agama (hifdzu al-dien). Hal ini menunjukkan bahwa pengundangan UU HAM merupakan salah-satu upaya agar tujuan diberlakukannya syariah Islam dapat berlaku maksimal di negara Indonesia. Harapannya ialah tidak ada lagi anggapan bahwa HAM bertentangan dengan Islam.

\section{DAFTAR PUSTAKA}

Abd. Wahid Wawan Gunawan, Muhammad Abdullah Darraz, Ahmad Fuad Fanani. Fikih Kebinekaan; Pandangan Islam Indonesia Tentang Umat, Kewargaan, dan Kepemimpinan non-Muslim. Bandung: Kerjasama Mizan Pustakadan Maarif Institute, 2015.

Al-Azhar Muzhaf, Al-Qur'an dan Terjemahannya. Bandung: Penerbit Hilal, 2010.

${ }^{35}$ Muwaffiq Jufri, “Kontribusi Konstitusi Madinah dan Konstitusi Nagarakretagama terhadap Rancangan UUD NRI 1945 terkait Hak dan Kebebasan Beragama", Tesis Program Magister Ilmu Hukum Universitas Brawijaya, 2016, h. 87-88.

36 Lihat ketentuan Pasal 10 Deklarasi Kairo. 
Ali Fahmi Agung, Implementasi Jaminan Hukum HAM Atas Kebebasan Beragama di Indonesia. Yogyakarta: Interpena, 2011.

Strategi Pemasyarakatan Hak Asasi manusia dalam Masyarakat yang Plural. Jurnal Konstitusi PKK Fakultas Hukum Universitas Trunojoyo Madura, Vol 11 No. 1 Juni 2011.

Ali Mafaz Salamun, "La Ikraha fiddin, Tafsir Humanis dalam Beragama".http://lifestyle. kompasiana.com/catatan/2013/04/23/la-ikraha-fid-ad-din-tafsirhumanis-dalam-beragama-554083.html.

Baidhawi Zakiyudin, Kredo Kebebasan Beragama. Jakarta: PSAP Muhammadiyah, 2005.

Deklarasi Kairo Tentang Hak Asasi Manusia.

Hasan Tholchah, Hak Sipil dan Hak Politik Rakyat dalam Wacana Fiqih, Jurnal Khazanah; Jurnal Aswaja dan Keislaman: Pusat Studi Aswaja dan Keislaman, Universitas Islam Malang. Edisi II Tahun 1999.

Jufri Muwaffiq, Kontribusi Konstitusi Madinah dan Konstitusi Nagarakretagama terhadap Rancangan UUD NRI 1945 terkait Hak dan Kebebasan Beragama. Tesis Program Magister Ilmu Hukum Universitas Brawijaya, 2016. - Pembatasan terhadap Hak dan Kebebasan Beragama di Indonesia, Jurnal Pendidikan Pancasila dan Kewarganegaraan, Vol. 1 No. 1, Februari 2016.

Komkelo Mujaid, Moh, Anas Kholish, Fiqh Vredian Aulia Ali. Fiqh HAM; Ortodoksi dan Liberalisme Hak Asasi Manusia dalam Islam. Malang: Setara Press, 2015.

Mas'udi Masdar Farid, Syarah UUD 1945 Perspektif Islam. Jakarta: Kerjasama Pustaka Alvabet dengan Lembaga Kajian Islam dan Perdamaian (LaKIP), 2013.

Muhshi Adam, Teologi Konstitusi; Hukum Hak Asasi Manusia Atas Kebebasan Beragama di Indonesia. Yogyakarta: LkiS, 2014.

Mujaid Kumkelo, dkk. Figh HAM; Ortodoksi dan Liberalisme Hak Asasi Manusia dalam Islam. Malang: Setara Press, 2015.

Nur Fuad Ahmad, dkk.. Hak Asasi Manusia dalam Prespektif Islam. Malang; Kerjasama antara Madani dengan LPSHAM Muhammadiyah Jawa Timur, 2010.

Nur Islami Muhammad, Hukum dan Kebebasan Berpikir. Yogyakarta: Pustaka Pelajar, 2015.

Pratiwi Cekly Setya, Penghormatan dan Perlindungan Hak Asasi Manusia: Hak Kebebasan Beragama dan Berkeyakinan di Indonesia. Dalam Syamsul Arifin, dkk (Editor), Hak Asasi Manusia Untuk Kebebasan Beragama di Indonesia; Keniscayaan, Kenyataan, dan Penguatan. Malang; PUSAM Bekerjasama dengan The Asia Fundation, 2015.

Undang-Undang Dasar Negara Republik Indonesia Tahun 1945.

Undang-Undang Nomor 39 Tahun 1999 Tentang Hak Asasi Manusia. 